\section{University College of the West Indies}

In is widely recognized that a degree course in agriculture should be available in the West Indies, and for some time the Council of the University College of the West Indies and the Governing Body of the Imperial College of Tropical Agriculture have considered how to provide it. The Governing Body of the Imperial College of Tropical Agriculture has recently proposed that the Imperial College should merge its identity in the University College of the West Indies and become its School of Agriculture. The Council of the University College has welcomed the proposal and is discussing means of giving effect to it in the near future. The degree course would replace the present course for the diploma of the Imperial College of Tropical Agriculture, but the other activities of the Imperial College, including its postgraduate teaching and research, would be continued in Trinidad under the auspices of the University College. At the request of the two Colleges the Secretary of State for the Colonies has agreed to the secondment of Sir Stephen Luke from the Colonial Office to assist them in the preparation of a scheme.

\section{Professional Civil Servants}

IN an article on "The Role of the Professional Civil Servant" reprinted from Scientific Service in State Service of August, Sir Graham Sutton expresses the view that in the future it will be increasingly necessary for professional Civil servants to participate in administrative functions: the management of a research group or of any part of a Ministry concerned with scientific and technical matters should be largely in the hands of men with professional knowledge. Sir Graham regards the making of decisions on the basis that he who is completely ignorant cannot be biased is a most dangerous feature of to-day and agrees, on the other hand, that the whole basis of scientific training makes it extremely difficult for the scientist or engineer to go against the weight of evidence. Accordingly, he suggests, a main problem facing professional Civil servants is how to ensure that an adequate knowledge of administration and management is passed on to the young professional man in his formative years. He believes that in any well-balanced government service of the future the fundamental position of the technically trained man must be recognized and that he should be given some training officially in administration. The professional Civil servant must endeavour to carry on the tradition of integrity, freedom from corruption and life-time devotion to duty irrespective of financial reward which had marked the Civil Service, but from the point of view that he is no longer an adviser, but likely to be the man who will actually make decisions because he alone is able to understand the scientific principles involved.

\section{Business Schools}

IN an article, "The American Business School", in the Westminster Bank Review of May last, Mr. O. S. Hiner describes briefly these institutions and their close relations with industry and with commerce, on which their effective operation depends. First degrees in commerce and business rose from 1,559 in 1920 to a peak of 72,137 in 1950 and were more than 40,000 in 1955. The expansion has been due partly to the readiness of the universities to recognize and meet a need, though the provision made has not always been commensurate with their facilities and available teaching staff. The American Association of Collegiate Schools of Business was formed to promote and raise standards, and 90 out of about 170 undergraduate and graduate schools are members. In the belief that decisions in business require increasingly managers with a wide, balanced outlook, the business schools are offering courses intended to produce the 'general' man rather than the specialist, and they claim that their task is primarily to help provide, not departmental heads, but general managers of the future. Besides consulting work by the staff, business schools often undertake research at the request of industry, and there is also a strong demand for development programmes intended to prepare men who have attained senior positions as specialists to undertake more general managerial responsibility. Mr. Hiner suggests that these schools constitute a vital element in the range of educational possibilities and that such institutes in Britain could fill a gap in our existing educational arrangements to produce the managers we need.

\section{Water Pollution}

THe Department of Scientific and Industrial Research is issuing a quarterly series of leaflets dealing with different aspects of water pollution and its control, one object of which is to direct the attention of industry to the work of the Water Pollution Research Laboratory, the scope of which is being extended with the help of a considerable financial contribution from the Federation of British Industries. The first of these leaflets (Notes on Water Pollution Research, No. 1, June 1958. Pp. 3. (Stevenage, Herts : Water Pollution Research Laboratory, D.S.I.R., 1958) ) deals with the effect of organic discharge on the level of oxygen in a stream. It points out that information is particularly required on the rate at which rivers of different depths will absorb oxygen from the air and states that particular attention is to be given to the study of this property of rivers in the future programme of the Laboratory.

\section{Animal Behaviour}

THE renewal of interest in the scientific study of animal behaviour, now generally known as ethology, which is one of the more remarkable features of the development of zoology in the past twenty-five years, has been marred by a lack of communication between the different schools of thought and between workers in different countries. This has given rise to a good many misunderstandings and needless arguments. In particular, the European school of behaviour students, who are mainly interested in the analysis of the more stereotyped kinds of behaviour of groups such as insects, birds and fish, were-partly as a result of the War-almost completely out of touch with the work of comparative psychologists (the 'rat psychologists') in the United States. These barriers have fortunately been falling rapidly in the past few years and there is now much less provincialism of outlook than there was. A welcome further step in the process of bringing two of these groups together is the metamorphosis of The British Journal of Animal Behaviour into a new journal to be entitled Animal Behaviour. This is the result of a liaison now established between the British members of the Association for the Study of Animal Behaviour, which was instituted in 1936 and published the original journal as the Bulletin of Animal Behaviour in 1938, and their American colleagues. This has resulted in a much enlarged journal, which is certainly necessary to cope with the 